DIGITAL COMMONS
@ UNIVERSITY OF SOUTH FLORIDA

Volume 2

Issue 1 Volume 2.1 (Spring 2012): Open Access

\section{ABO: Interactive Journal for Women in the Arts, 1640-1830}

2012

\title{
Women's Literacy in Early Modern Spain and the New World, ed. by Anne J. Cruz and Rosilie Hernández
}

\author{
Kirsten Schultz \\ Seton Hall University, kirsten.schultz@shu.edu
}

Follow this and additional works at: https://digitalcommons.usf.edu/abo

Part of the Dramatic Literature, Criticism and Theory Commons, Educational Methods Commons, Feminist, Gender, and Sexuality Studies Commons, and the Literature in English, British Isles Commons

\section{Recommended Citation \\ Schultz, Kirsten (2012) "Women's Literacy in Early Modern Spain and the New World, ed. by Anne J. Cruz and Rosilie Hernández," ABO: Interactive Journal for Women in the Arts, 1640-1830: Vol.2: Iss.1, Article 19. http://dx.doi.org/10.5038/2157-7129.2.1.18 \\ Available at: https://digitalcommons.usf.edu/abo/vol2/iss1/19}

This Reviews is brought to you for free and open access by Digital Commons @ University of South Florida. It has been accepted for inclusion in ABO: Interactive Journal for Women in the Arts, 1640-1830 by an authorized administrator of Digital Commons @ University of South Florida. For more information, please contact digitalcommons@usf.edu. 
Women's Literacy in Early Modern Spain and the New World, ed. by Anne J. Cruz and Rosilie Hernández

\section{Keywords}

Americas, education, gender, libraries, literacy, material culture, reading, review, Spain

Creative Commons License

(c) $($ ) $\odot$

This work is licensed under a Creative Commons Attribution-No Derivative Works 3.0 License. 
Anne J. Cruz and Rosilie Hernández, eds. Women's Literacy in Early Modern Spain and the New World. Burlington, VT: Ashgate, 2011. Xii + 274pp. Index. ISBN: 978-1-4094-2713-1.

Reviewed by Kirsten Schultz, Seton Hall University, kirsten.schultz@shu.edu

The early modern Spanish and Spanish-American women brought forth in this engaging collection of essays had complex experiences with language and the written word. They listened (to sermons, readings, songs, and the dialogue of actors on stage), they read, and they wrote. They did all of these things within cultures (metropolitan and colonial) in which humanists and Tridentine Catholic leaders inveighed against women's access to books and protested against women's writing as an immoral act. In this sense, women's literacy constituted a kind of subculture. Yet perhaps what is most striking about the history of women's literacy that emerges out of this collection is the extent to which women in early modern Spain and the Spanish empire listened, read, and wrote at the very centers of social, religious, and political power. If women's literacy took shape in the contexts of devotion and domestic duties, it was also the case that the Church and the elite household were spaces, often with direct links to royal and vice-regal courts, where early modern Spaniards and Spanish Americans forged notions of authority that shaped, at least in part, society and culture overall. Building on earlier research, including that of several of the pioneering scholars included here, and offering new evidence and analyses, Women's Literacy in Early Modern Spain and the New World illuminates both the ideas and practices that gendered knowledge and education and the ways in which women contended with the limits on, and opportunities for, reading and writing.

The collection is divided into three parts. The first part on "The Practices of Women's Literacy" integrates the history of libraries and books and new perspectives on the gendered ways in which men and women experienced the written word in the early modern Spanish world. In "Women's Reading Habits: Book Dedications to Female Patrons in Early Modern Spain" Nieves Baranda Leturio analyzes the complex ways in which male authors and translators used dedications to construct archetypes of female readers. Drawing on dedications in 500 Spanish works published between 1500 and 1700, Baranda Leturio points to the ways in which dedications transmitted social values. Yet dedicatees also acted as agents of book production and thus elite women (not only queens and members of the royal family) conditioned "the books' contents and other potential readers" to an extent that has not been recognized previously (31). Anne J. Cruz also examines the complex relationship between elite women and books in "Reading over Men's Shoulders: Noblewomen's Libraries and Reading Practices." Based on the trajectories of two women from powerful noble families, Cruz shows that if the experience of literacy often took shape in the space of a male relative's library, propertied women could become collectors of books, and, in reading books that belonged to their fathers, daughters "inherited" knowledge and the capacity to disseminate that knowledge to others (53). In Montserrat Pérez-Toribio's "From Mother to Daughter: Educational Lineage in the Correspondence between the Countess of Palamós and Estefania de Requesens," the analysis of literacy shifts to the question of dissemination and from books and reading to letters and writing. While humanists, such as Juan Luis Vives, recognized as legitimate the mother's role as educator during early childhood, they also insisted that her knowledge and deployment of the epistolary genre was potentially threatening to her and her children's morality. In the letters exchanged between a countess and 
her daughter, however, Pérez-Toribio finds evidence of not only female support and efforts to provide a proper education in household management but also an exchange of thoughts on matters that did not concern domesticity per se. In assuming domestic authority, letter writers such as the countess challenged the ways in which motherhood was defined by men as dependency. As Trevor J. Dadson shows in "The Education, Books and Reading Habits of Ana de Mendoza y de la Cerda, Princess of Éboli (1540-1592)," the legacy of educated mothers can be traced through the lineages of many of the most powerful noble families in Spain. The intellectual life of Ana de Mendoza was forged in her mother's large library that included, among other titles, the novels of chivalry that contemporary moralists decried. Her education then served her as she strove to prevail over the adversities that came from her father's infidelities and wrote to the king to complain about her misfortunes and the powerful courtiers behind them. However, it did not spare her the imprisonment, without charges brought, ordered by Philip II in 1579 .

The predicaments of physical confinement are interrogated in part two, "Conventual Literacy in Spain and the New World." While convents, Cruz observes, were "the most democratic and the principal sources of literacy instruction for early modern women" (9), as Clara E. Herrera shows in "Convent Education in Nueva Granada: White and Black, or Tonalities of Gray?" the educational infrastructure for women of more modest origins was, if limited, also complex and developed over time, even in areas far from metropolitan and vice-regal power. Convents also produced two of the most well-known women authors of the early modern European world: Teresa of Ávila and Sor Juana Inés de la Cruz. The contributions here by Darcy R. Donahue, Elizabeth Teresa Howe, and Stephanie L. Kirk together reexamine the ways in which these women engaged and disrupted Christian views of female literacy which had crystalized around the Pauline dictum of women's silence. While in "Wondrous Words: Miraculous Literacy and Real Literacy in the Convents of Early Modern Spain," Donahue analyzes the Carmelites' embrace of Saint Teresa's literacy to configure their own literacy as integral to convent life, she also observes how they attributed literacy to divine intervention. As Howe explains in "'Let Your Women Keep Silence': The Pauline Dictum and Women's Education” Saint Teresa herself understood both her literacy and her silent world as a gift from God. Howe and Kirk, in "Women's Literacy and Masculine Authority: The Case of Sor Juana Inés de la Cruz and Antonio Núñez de Miranda," revisit the life and work of Sor Juana, who, as Howe observes, drew on the example of Saint Teresa but also struggled with Pauline dictum. While Howe points to the ways in which Sor Juana read Paul and other passages from scripture to argue for women's God-given talent to study and teach, Kirk analyzes the relationship between Sor Juana and her confessor, a Jesuit threatened by the extent to which Sor Juana's erudition rivaled his own formidable talent. The owner of the largest private library in New Spain, Sor Juana confronted her confessor's authority and his disapproval of her public display of poetic virtuosity by denouncing his own role in publicizing what for her was a private matter. If, like other educated women identified in this collection, her life ended without vindication of her learning, today, Kirk observes, it is her work, and not that of her confessor, that forms part of literary canon.

The essays in part three, "Representing Women's Literacy in Art and Literature," turn to representations, often intertextual, of educated women and women becoming educated, but also revisit the questions of practice and discourse taken up in this volume's first two parts. Adrienne L. Martin in "Learning through Love in Lope de Vega's Drama" shows how the playwright 
portrayed a woman's education in the context of love, dramatizing "the Aristotelian notion of potentiality" in a way that affirmed that the goal of education was marriage (188-89). The essays by Alicia R. Zuese and Yolanda Gamboa-Tusquets return to women writers, now in early modern academies, spaces that afforded alternatives to devotional and domestic ones and, as Zuese argues in "Ana Caro and the Literary Academies of Seventeenth-Century Spain," a path towards social and political agency. In "Maria de Zayas, or Memory Chains and the Education of a Learned Woman," Gamboa-Tusquets traces Zayas's education in academies and her commitment to constructing a female genealogy of erudition. The last two essays examine contested representations of holy women. Rosilie Hernández in "The Politics of Exemplarity: Biblical Women and the Education of the Spanish Lady in Martín Carrillo, Sebastián de Herrera Barnuevo, and María de Guevara" analyzes efforts to re-interpret a tradition of female exemplars in order to find grounding for women's unrealized political capacity. In "Learning at her Mother's Knee? Saint Anne, the Virgin Mary, and the Iconography of Women's Literacy," Emilie L. Bergmann illuminates the extent to which images of Saint Anne and "The Education of the Virgin" endured in spite of the Council of Trent's injunctions against their production. Bergmann concludes that Spanish art evinced "a persistent visual linking of women with books" (260). Indeed, as the essays in this collection show, within elite culture and among female religious, women's encounters with books and the written word time and again provided points of departure for their broader social, cultural, and, in some cases, emergent political experiences. 